\title{
Drivers of Vertical Intra-Industry Trade: The Case of the Hungarian Agri-Food Sector
}

\section{Imre Fertón ${ }^{a b}$ and Attila Jámbor ${ }^{a}$}

${ }^{a}$ Institute of Economics - Centre for Economic and Regional Studies, Hungarian Academy of Sciences, 1112 Budapest, Budaörsi út 45, Hungary

${ }^{\mathrm{b} C}$ Corvinus University of Budapest, 1093 Budapest, Fővám tér 8, Hungary. E-mail: imre.ferto@krtk.mta.hu

\section{Introduction}

Traditional trade theories assume constant returns to scale, homogenous products and perfect competition and aim to explain inter-industry trade based on comparative advantages. However, a significant portion of the world trade since the 1960 s took the form of the intra-industry rather than inter-industry trade. From the 1970's, an increasing amount of research started to deal with this issue, providing a theoretical basis for intra-industry trade (IIT), defined as the simultaneous export and import of products belonging to the same statistical product category. According to the pioneering work of Falvey (1981), notions of horizontal and vertical product differentiation have come into existence in the literature. Horizontal intra-industry trade (HIIT) refers to homogenous products with the same quality but with different characteristics, while vertical intra-industry trade (VIIT) means products traded with different quality and price. Following Falvey's work, three types of bilateral trade flows may occur between countries: inter-industry trade, HIIT and VIIT.

Since the 1990s, intra-industry trade (IIT) has become a widespread phenomenon with growing role in international trade (Brülhart 2009). The formation of stronger economic ties between European countries due to the creation and expansion of the EU contributed to an increase in intra-industry trade among European countries. The previous two decades in Central and Eastern European countries also reoriented their trade from within former Soviet bloc states to EU member countries and the share of IIT with the EU also increased. 
Evidence is also growing of the dominant role of VIIT in total IIT (e.g. Fontagné et al. 2006, Jensen and Lüthje 2009), highlighting the importance of respective theoretical models for empirical analysis. However, significant part of the studies still has focused on industrial products, while agri-food sectors are usually neglected in empirical works. The main reason is probably that agricultural markets are usually assumed to be perfectly competitive. However, research on the characteristics of food markets suggests that these markets are typically oligopolistic (Sexton and Lavoie, 2001; Sheldon and Sperling, 2003). Hirsch and Gschwandtner (2013) proved that the degree of profit persistence in the food industry is indeed lower compared with other manufacturing sectors due to strong competition among food processors and high retailer concentration. Nevertheless, they still find a large number of firms with longrun profits that are not eroded by the competitive process, thus also contradicting the theory of perfect competition. In addition, recent studies suggest that the role of IIT has been increasing in agricultural trade for both developed and developing countries (e.g. Leitao 2011; Rasekhi and Shojaee 2012; Wang 2009; Varma 2012). Moreover, recent studies confirm the existence of market power in pork and dairy sectors in Hungary (Bakucs et al 2010, Hockmann and Vöneki 2009, Perekhozhuk et al 2013).

The aim of the paper is to examine the drivers of vertical intra-industry agri-food trade between Hungary and the EU. Such an approach aims to contribute to the literature of the field in three ways: (1) focusing on agri-food products, (2) distinguishing between horizontal and vertical IIT and (3) analyzing the impacts of EU accession as well as regional trade on Hungarian agri-food trade.

In order to do so, the paper is structured as follows. The next section presents the theoretical foundation of the empirical model. Section 3 provides empirical evidence on IIT in the agrifood sector of the New Member States. Section 4 outlines the separation of horizontally and vertically differentiated products and the three approaches to measuring IIT, and these 
approaches are applied to our data set in section 5. The theoretical basis for investigation of the country-specific determinants of IIT is outlined in section 6, and the results of the regression analysis are presented in section 7 . Section 8 contains a summary and some conclusions.

\section{Theoretical framework}

The theoretical models emphasize three important factors explaining VIIT which are important for both demand and supply side: the role of differences in factor endowments, effect of income distribution and production size. The first strand of models focuses on the comparative advantage explanation of VIIT, as in the Heckscher-Ohlin model. Falvey (1981) assumes a

perfectly competitive market with two countries, two goods (a homogeneous product and a differentiated one) and two factors (labour and capital). He introduces technological differences between countries but only in the homogeneous product sector. In the differentiated sector it is assumed that more capital is used in producing higher quality varieties than in lower quality ones. So, the higher income, relatively capital-abundant country specializes in exporting relatively high quality varieties, while the lower income, relatively labor-abundant country specializes in exporting low quality varieties. Falvey's model does not have an explicit demand side, but Falvey and Kierzkowski (1987) also elaborate this.

On the demand side, goods are distinguished by perceived quality. Although all consumers have the same preferences, each individual demands only one variety of the differentiated product, which is determined by their income. Given that aggregate income is not equally distributed, consumers with lower incomes will demand low-quality varieties, and high-income consumers will demand high qualities, regardless of their country of origin. Thus, it is possible to establish a marginal level of income in such a way, that those consumers with higher earnings will purchase the varieties produced in the relatively capital-abundant country, while low-income consumers will purchase the varieties produced in the relatively labor-abundant country. In this 
framework, intra-industry trade exists because each variety of a differentiated good is produced in only one country but is consumed in both countries. In a two-country world, the country which is relatively labor-abundant will tend to export the lower quality/labor intensive varieties of a differentiated good demanded abroad by low-income consumers and will tend to import the higher quality/capital intensive varieties demanded by high-income consumers in that country. Thus, the greater IIT is, the greater differences in the relative factor endowments (which correspond to per-capita income differences in the context of the model) between two countries are. The model also suggests that VIIT is positively correlated with differences in the pattern of income distribution between partner countries.

The second group of the models turns to a more heterodox explanation in line with the neoRicardian and neo-factorial models (Gabszewicz et al. 1981, Shaked and Sutton 1984). A similar model of IIT in vertically differentiated products to Flam and Helpman (1987) is created in which North-South trade is determined by differences in technology, income and income distribution. Results of this model are very similar to those of Falvey and Kierzkovski (1987). In the model of Flam and Helpman, there are two countries: a home country (North) and a foreign country (South), one factor (labor) and two goods. One of the goods is homogeneous and perfectly divisible, while the other good is quality differentiated and indivisible. Both countries have the same unit labor requirements for producing the homogeneous good. Labor input per unit of output of the quality differentiated products differs between countries, where quality is a positive function of the labor input. The home country has an absolute advantage in production of all qualities, whilst the foreign country may have a comparative advantage in low quality variety. Note that the source of quality differentiation is not the amount of capital used in producing the good, like in the Falvey and Kierzkowski (1987) model, but the technology used. 
Demand for varieties stems from variation in income across consumers who buy a specific quality reflecting their preferences and income constraint. Consumers with higher effective labor endowments (who are assumed to earn higher income) demand the higher quality indivisible good. Therefore, the home country specializes completely in the differentiated good of high quality, whilst the foreign country exports the homogeneous good. Assuming an overlap in income distribution, IIT appears. The model predicts that higher bilateral differences in factor endowment lead to a higher share of IIT.

Stokey (1991) and Copeland and Kotwal (1996) also assign a different aspect of the income distributions explaining VIIT. Moreover, the level of income per capita is determined by the capital intensity, thus the capital-abundant countries have relatively higher income per capita, and the labor-abundant countries have relatively lower income per capita. Thus, the model predict that VIIT to be more prominent among countries with a high degree of income distribution overlap.

\section{Empirical evidence}

Although the importance of IIT is already well documented in agri-food sectors in the late nineties (Fertő, 2005), research in the last decade remained still limited on the drivers of agrifood IIT. Wang (2009) investigated IIT for China's agricultural products between 1996 and 2005 showing a relatively low level of IIT with continuously increasing trend. Varma (2012) analyzed the extent of intra-industry trade in India's agricultural trade highlighting a mild tendency for IIT to increase during the period of 2000-2008. Fertő (2007) analyzed Hungarian intra-industry agri-food trade patterns with EU15 and confirmed that determinants of HIIT and VIIT differed. Horizontal intra-industry trade was negatively associated with differences in per capita income, average GDP, distance and distribution of income, while income and distance were positively related to VIIT. Leitao and Faustino (2008) investigated the determinants of 
intra-industry trade in the Portuguese food processing sector and found that IIT was positively influenced by GDP per capita differences and energy consumption, while it was negatively related to physical endowments, relative size effects and geographical distance. Leitao (2011) focused on the determinants of United State's agricultural IIT and showed that it was positively influenced by average GDP, FDI and trade imbalance, while it had a negative relationship with differences in per capita GDP. Rasekhi and Shojaee (2012) investigated country specific determinants of vertical and total intra-industry trade between Iran and its main trading partners and revealed that VIIT was positively influenced by land endowments, but negatively affected by the size of trading partners.

In short, studies highlighted the increasing role of intra-industry trade in agri-food trade for some developed and developing countries. In addition, in line with recent empirical evidence, papers confirm that HIIT and VIIT are influenced by different factors (Fertö 2005, Leitao, 2011).

The second strand of empirical literature concentrates on the importance of IIT on agri-food sectors in the New Member States (NMS), meaning those countries that acceded to the European Union in 2004 or 2007. Caetano and Galego (2007) investigated the determinants of intra-industry trade within an enlarged Europe and also found that determinants of HIIT and VIIT differed, although both had a statistically significant relationship with a country's size and foreign direct investment. According to their results, country size, income per capita differences and geographic distance were found to be important factors for IIT, especially for HIIT. Jensen and Lüthje (2009) analyzed the determinants of VIIT in Europe and identified production size, geographical proximity, average income per capita and income distribution overlap as the major ones. It was shown that countries characterized by being on a high economic level and by being large economies had a higher bilateral VIIT with each other than with other countries. Furthermore, countries with large income distribution overlap tended to 
have a large VIIT, while countries far from each other had lower VIIT than countries close to each other.

Gabrisch (2009) investigated VIIT between old and new member states of the EU and found that country-pair fixed effects to be of high relevance for explaining vertical intra-industry trade. His results suggest that technology differences were positively, while differences in factor endowments were negatively correlated with vertical intra-industry trade. Moreover, changing bilateral differences in personal income distribution during the transition of NMS was found to have contributed to changes in vertical intra-industry trade.

Černoša (2009) tests the industry-specific hypothesis for Slovenia before EU accession. He found that VIIT was predominant within total IIT and his results provide strong support for the effects of industry-specific determinants of VIIT.

Fainštein and Netšunajev (2011) analyzed intra-industry trade dynamics for Estonia, Latvia, and Lithuania in 1999-2007. Their results show that shares of IIT have increased within the period, with VIIT dominating. Shares of total HIIT and VIIT have grown since 2004, the year of accession to the European Union. They find market size, distance and human capital to be important in the Baltic states for IIT in general and for HIIT in particular.

Ambroziak (2012) investigated the relationship between FDI and IIT in the Visegrad countries and found that FDI stimulated not only VIIT in the region but also HIIT. He found that differences in country size and income were positively related to IIT as was FDI, while distance and IIT showed a negative relationship.

In sum, research on IIT in NMS confirms the dominance of VIIT over HIIT. Results also imply the distinction between HIIT and VIIT play important role to explain the drivers of IIT. Table 1 provides an overview of the key empirical studies and their results listed above.

\section{PLEASE INSERT TABLE 1 HERE}




\section{Measuring vertical and horizontal intra-industry trade}

The basis for the various measures of IIT used in the present study is the Grubel-Lloyd (GL) index (Grubel and Lloyd 1975), which is expressed formally as follows:

$$
G L_{i}=1-\frac{\left|X_{i}-M_{i}\right|}{\left(X_{i}+M_{i}\right)}
$$

where $\mathrm{X}_{\mathrm{i}}$ and $\mathrm{M}_{\mathrm{i}}$ are the value of exports and imports of product category $\mathrm{i}$ in a particular country. The GL index varies between 0 (complete inter-industry trade) and 1 (complete intraindustry trade) and can be aggregated to level of countries and industries as follows:

$$
G L=\sum_{i=1}^{n} G L_{i} w_{i} \text { where } w_{i}=\frac{\left(X_{i}+M_{i}\right)}{\sum_{i=1}^{n}\left(X_{i}+M_{i}\right)}
$$

where $\mathrm{w}_{\mathrm{i}}$ denotes the share of industry $\mathrm{i}$ in total trade.

Literature suggests several options to disentangle HIIT and VIIT. Greenaway et al. (1995) developed the following approach (abbreviated as GHM from now on): a product is horizontally differentiated if the unit value of export compared to the unit value of import lies within a $15 \%$ range, otherwise they define vertically differentiated products. Formally, this is expressed as follows:

$1-\alpha \leq \frac{U V_{i}^{X}}{U V_{i}^{M}} \leq 1+\alpha$

where UV means unit values, $\mathrm{X}$ and $\mathrm{M}$ means exports and imports for goods $\mathrm{i}$ and ${ }_{\alpha}=0.15$. Furthermore, Greenaway et al. (1995) added that results coming from the selection of the $15 \%$ range do not change significantly when the spread is widened to 25\%. Blanes and Martín (2000) emphasize the distinction between high and low VIIT. They define low VIIT (abbreviated as VLIIT from now on) when the relative unit value of a good is below the limit of 0.85 , while unit value above 1.15 indicates high VIIT (abbreviated as VHIIT from now on). 
Based on the logic above, the GHM index comes formally as follows:

$G H M_{k}^{p}=\frac{\sum_{j}\left[\left(X_{j, k}^{p}+M_{j, k}^{p}\right)-\left|X_{j, k}^{p}-M_{j, k}^{p}\right|\right]}{\sum_{j}\left(X_{j, k}+M_{j, k}\right)}$

where $\mathrm{X}$ and $\mathrm{M}$ denote export and import, respectively, while $\mathrm{p}$ distinguishes horizontal or vertical intra-industry trade, $\mathrm{j}$ is for the number of product groups and $\mathrm{k}$ is for the number of trading partners $(\mathrm{j}, \mathrm{k}=1, \ldots \mathrm{n})$.

Fontagné and Freudenberg (1997) propose a different method (abbreviated as FF from now on) in the literature for categorizing trade flows and computing the share of each category in total trade. They defined trade to be "two-way" when the value of the minority flow represents at least $10 \%$ of the majority flow. Formally:

$$
\frac{\operatorname{Min}(X i, M i)}{\operatorname{Max}(X i, M i)} \geq 10 \%
$$

If the value of the minor flow is below $10 \%$, trade is classified as inter-industry in nature. If the opposite is true, the FF index comes formally as:

$$
F F_{k}^{p}=\frac{\sum_{j}\left(X_{j, k}^{p}+M_{j, k}^{p}\right)}{\sum_{j}\left(X_{j, k}+M_{j, k}\right)}
$$

where notation $\mathrm{p}, \mathrm{j}, \mathrm{k}$ are the same as above. After calculating the FF index, trade flows can be classified as follows: horizontal two-way trade, vertical two-way trade and one-way trade. According to Fontagné and Freudenberg (1997), the FF index tendentiously provides higher values compared to GL-type indices (like the GHM index) as equation 5 refers to total trade, treated before as two-way trade. The authors suggest that the FF index rather complements than substitutes GL-type indices as they have measured the relative weight of different trade types in total trade. In conclusion, they found that the value of GHM index is usually between the GL and FF index. 
Previous indices measure the share of intra-industry trade instead of its level. Nilsson (1997) suggests a new indicator (abbreviated as $\mathrm{N}$ from now on) that matched trade [i.e. the same numerator as GHM in (4)] is divided by the number of products traded, n, to yield an average level of IIT per product. Fertő (2005) applied this logic to HIIT and VIIT and formally expressed the $\mathrm{N}$ index as:

$N_{k}^{p}=\frac{\sum_{j}\left\lfloor\left(X_{j, k}^{p}+M_{j, k}^{p}\right)-\left|X_{j, k}^{p}-M_{j, k}^{p}\right|\right]}{n^{p}}$

where the numerator equals to that of the GHM index, while $\mathrm{n}$ refers to the number of product groups in total trade. Nilsson (1997) argues that his measure provides a better indication of the extent and volume of IIT than GL-type indices and is more appropriate in cross-country IIT analyses.

Due to the discussed reasons, we employ all the three methods (GHM, FF and N) in the paper for trade data coming from the Eurostat COMEXT database using the HS6 system (six digit level). Agri-food trade is defined as trade in product groups HS 1-24, resulting in 964 products using the six digit breakdown. Various VIIT indices are aggregated for each pair of countries as described in equations $(4,6,7)$. Our analysis focuses on the period 1999-2010. In this context, the EU is defined as the member states of the EU27. Moreover, empirical research is based on the shares of VIIT.

\section{Hypotheses and econometric specifications}

Following the theoretical and empirical research we test the following hypotheses.

H1. Difference in factor endowments between trading partners increases the share of VIIT in total trade. 
Difference in factor endowments is a key variable when explaining VIIT. In the empirical literature factor endowments are usually proxied by GDP per capita. Relative factor endowments, measured by the logarithm of the absolute value of the difference in per capita GDP (lnDGDPC), are expected to be positively related to the share of VIIT. Per capita GDP is measured in PPP in current international dollars and data comes from the World Bank World Development Indicators (WDI) database.

However, the use of per capita GDP as a proxy for relative factor endowments is problematic. Linder (1961) already noted that inequality in per capita income may serve as a proxy for differences in preferences as suggested. In addition, Hummels and Levinsohn (1995) argued that this proxy is appropriate only when the number of factors is limited to two and all goods are traded, thus they proposed income per worker as a measure for differences in factor composition. Interestingly, despite of these limitations of use of the GDP per capita, it became a popular and dominating proxy for factor endowments in empirical literature. However, the nature of factor endowments may also play an important role in specialization in quality ranges. Thus, it is necessary to use more variables to consider various aspects of factor endowments including physical, technological and human capital. The standard solution is to employ investment in physical capital, R\&D expenditures and education expenditure (e.g. MilgramBaleix and Moro-Egido 2010).

Note that our focus is on agri-food trade, thus we employ more agricultural related factor endowments variables. More specifically, we concentrate on three traditional agricultural factors including land, labor and capital. Consequently, we measure relative agricultural factor endowments by the logarithm of the absolute value of difference in agricultural land, labor and machinery (lnDLAND, lnDLAB, lnDMACH) between Hungary and its trading partners, which are expected to be positively related to the share of VIIT. Agricultural land is measured in million hectares (source: FAO), agricultural labor is measured in 1000 annual working units 
(source: Eurostat), while agricultural machinery is measured in euro (source: Farm Accountancy Data Network, FADN).

H2. The growth of average economic size increases the share of VIIT in total trade.

The larger the international market, the larger the opportunities for production of differentiated intermediate goods and the larger the opportunities for trade in intermediate goods. The logarithm of the average GDP of trading partners is used as a proxy for the average size of markets. AVGDP is measured in PPP in current international dollars and the source of data is also the World Bank WDI database. A positive sign for VIIT is expected.

H3. The more unequal income distribution in trading partners increases the share of VIIT in total trade.

Following Falvey and Kierzkowski (1987), we hypothesize that unequal income distribution suggests different demand patterns between trading partners and thereby the need for qualitydifferentiation (associated with VIIT) arises. This hypothesis is tested by using the logarithm of the absolute value of the difference in the GINI-index between Hungary and EU27, which is expected to be positively related to the share of VIIT. Data for the lnDGINI variable is coming from the World Bank WDI.

H4. VIIT will be greater the closer the countries are geographically.

The distance between countries reflects transport costs. Variable lnDIST indicates the geographic distance between the reporting country and each of its trading partners by calculating the logarithm of the distance between the capital cities of trading partners in 
kilometres. The source of data is database of the French research center in international economics (CEPII). LnDIST is expected to be negatively related to VIIT.

H5: VIIT will be greater if NMS export agri-food produce to NMS markets.

Previous studies (Fertő and Soós 2009; and Bojnec and Fertő 2012) show that the duration of trade in both manufacturing and agri-food products differs across EU10/12 and EU15 markets: for the majority of countries, the length of trade is greater in EU10/12 markets than in EU15 markets. This hypothesis is tested by a dummy variable - it is 1 if the partner country is a New Member State and 0 if not.

H6: The EU accession has a positive impact on the share of VIIT.

After almost a decade, the question arises whether EU accession had any impact on NMS agrifood trade patterns and especially on intra-industry trade. It is generally accepted that economic integration increases intra-industry trade (McCorriston and Sheldon 1991, Qasmi and Fausti 2001). This hypothesis, similarly to the previous one, is tested by a dummy variable with value of 1 if the reporter country is an EU member and 0 if not.

We test the model by Flam and Helpman (1987) with two baseline specifications. $\operatorname{lnIIT} \mathrm{ijt}_{\mathrm{jit}}=\alpha_{0}+\alpha_{1} \operatorname{lnDGDPC}_{\mathrm{ijt}}+\alpha_{2} \operatorname{lnDAVGDP} \mathrm{ijt}_{\mathrm{ijt}}+\alpha_{3} \operatorname{lnDGINI} \mathrm{nIjt}_{\mathrm{jt}}+\alpha_{4} \operatorname{lnDIST}_{\mathrm{ijt}}+\alpha_{5} \mathrm{NMS}_{\mathrm{t}}+\alpha_{6} \mathrm{EU}+$ $\varepsilon_{\mathrm{ijt}}$

$\operatorname{lnIIT} T_{\mathrm{ijt}}=\alpha_{0}+\alpha_{1} \operatorname{lnDLAND}_{\mathrm{ijt}}+\alpha_{2} \operatorname{lnDLAB}_{\mathrm{ijt}}+\alpha_{3} \operatorname{lnDMACH} \mathrm{nD}_{\mathrm{ijt}}+\alpha_{4} \operatorname{lnDAVGDP} \mathrm{P}_{\mathrm{ijt}}+\alpha_{5} \operatorname{lnDGINI} \mathrm{nijt}_{\mathrm{ijt}}+$ $\alpha_{6} \operatorname{lnDIST} \mathrm{T}_{\mathrm{ijt}}+\alpha_{7} \mathrm{NMS}_{\mathrm{t}}+\alpha_{8} \mathrm{EU}+\varepsilon_{\mathrm{ijt}}$

where $\mathrm{i}$ describes Hungary, $\mathrm{j}$ denotes partner country and $\mathrm{t}$ is year. 
Table 2 provides an overview of the description of variables and related hypotheses.

\section{PLEASE INSERT TABLE 2 HERE}

\section{The nature of intra-industry trade}

Using the methods outlined above, we compute measures of IIT in horizontally and vertically differentiated agri-food products between Hungary and 26 member states of the EU, for the period 1999 to 2010, using Eurostat data. From the average measures of GHM, FF and N over the period, Hungary's IIT in agri-food products with its EU partners was increasing (Figure 1). The three indices yield a relatively good consistency for ranking countries according to the share of HIIT and VIIT, the nine possible pairings show a high level of correlation $(>0.85)$. It seems also evident from Figure 1 that all indices show a general increase in the share of IIT after 2004 (the year of Hungarian EU accession), compared to years before accession.

\section{PLEASE INSERT FIGURE 1 HERE}

Furthermore, there is evidence of IIT, mainly of vertical nature, suggesting the exchange of products of different quality (Figure 2). The dominance of vertical over horizontal type trade accords with the general findings of recent empirical literature. Simple t tests suggest that Hungary specializes in larger shares of lower than higher qualities of agri-food products irrespective to various IIT indices. Interestingly, we find some evidence on the difference between the two market segments of the EU. Kruskal-Wallis tests reveal that the share of high and low VIIT is significantly higher in the OMS than in the NMS, while the share of HIIT does not differ across market segments. In the rest of this paper, we abstract from the horizontal term 
of the various indices of IIT, and focus only on VIIT. This means that we keep about 84 per cent of Hungarian IIT with the EU countries.

\section{PLEASE INSERT FIGURE 2 HERE}

\section{Econometric issues}

Recently, empirical IIT literature employs panel data to test theoretical IIT predictions. Despite of recent development of panel data econometrics, papers usually apply simple static random or fixed effect panel models. However, the empirical IIT analysis should face various challenges highlighted by econometric research.

The first task before estimating any panel regression models is to test stationarity of data using panel unit root tests. However, there are some additional issues to be addressed which usually do not take into account in empirical IIT research. First, heteroskedasticity may occur because trade between two smaller countries or between a smaller and larger country is probably more volatile than trade between two larger countries. The panel dataset is also subject to the existence of autocorrelation. Contemporaneous correlation across panels may occur because exporting to one country can take place as an alternative to exporting to another country. Similarly, adjacent exporter(s)'/importer(s)' time specific shocks result in larger correlated error terms of their trade with their partners.

Since some of the key variables of interest (distance, EU, NMS) are time-invariant, their impact on VIIT in goods cannot be estimated with a conventional fixed effects estimator as identification of the parameters relies on the time variation within each cross section. Empirical trade literature especially using gravity models offers two approaches to solve fixed effects issues. The first method typically applied is the Hausman-Taylor's panel which incorporates 
time-invariant variables correlated with bilateral specific effects (Hausman and Taylor 1981). An alternative solution is the different 'two-step'-type estimator proposed recently by Plümper and Tröger (2007). Their model labeled 'fixed effects vector decomposition (FEVD)' can be seen as a rival specification for the Hausman-Taylor approach in estimating the full parameter space in the model including both time-varying and time-fixed regressors (see recent trade applications by Davies et al. 2008). Plümper and Tröger (2007) and Mitze (2012) using MonteCarlo simulations show that FEVD is a preferable approach for small samples if time-invariant variables and the other variables are correlated with specific effects.

Moreover, Baltagi et al. (2003) have shown that when endogeneity among the right-hand-side regressors matters, the OLS and random effects estimators are substantially biased and both yield misleading inference. Recent literature highlights the potential endogeneity between trade flows and GDP related variables. Dynamic panel framework is appropriate to solve serial correlation, heteroskedasticity and endogeneity of some explanatory variables. The generalized method of moments (GMM) estimator, developed by Arellano and Bover (1995) and Blundell and Bond (1998), also referred to as the GMM-system estimator, can solve these problems. Moreover, the GMM estimator is efficient for panels with short time series (t) and large sample size (n), just like our one (Baltagi, 2008). Windmeijer (2005) proposes a finite sample correction that provides more accurate estimates of the variance of the two-step GMM estimator (GMM-SYS).

Last but not least, it is worth analyzing whether correlation exists between the explanatory variables of the model. The correlation matrix (Table 3) shows that there are no strong correlations among time-variant explanatory variables including correlation between $\ln$ DGDPC and lnAVGDP. The highest positive correlation is observable between lnAVGDP and lnDLAND (0.44), while the lowest negative exists between $\operatorname{lnDMACH}$ and $\operatorname{lnDLAB}(-0.20)$. 


\section{PLEASE INSERT TABLE 3 HERE}

\section{Regression results}

In line with the previous section, we have first pre-tested the model variables for unit root tests. A number of panel unit root tests are available. Considering the well-known low power properties of unit root tests, in this paper we employ a battery of unit root tests: Levin, Lin and Chu (2002) method (common unit root process), Im, Pesaran and Shin (2003) method (assuming individual unit root processes), ADF-Chi square, and PP-Chi square. Table 4 presents the results of four different panel unit root tests (Levin, Lin and Chu; Im, Pesaran and Shin; ADF-Fisher Chi square, PP-Fisher Chi square), with different deterministic specifications (with constant, and with constant and trend). The lag length has been chosen according to the Modified Akaike Information Criterion (MAIC) proposed by Ng and Perron (2001).

\section{PLEASE INSERT TABLE 4 HERE}

The IIT variables do not have unit roots, i.e. are stationary, with individual effects and individual trend specifications (Table 4). In order to ensure that variables are stationary $\mathrm{I}(0)$ and not integrated of a higher order, we apply unit root tests on first differences of all variables. All tests (not shown here) reject the unit root null hypothesis for the first differences. In sum, we may conclude that the panel is likely to be stationary. Similarly, we also check unit root tests on first differences and we can reject that variables are integrated in higher order. In short, our data is not appropriate for panel cointegration analysis. 
To address various econometric issues we apply three different econometric approaches. First, preliminary analysis using likelihood ratio tests, Wooldridge (2002) test for autocorrelations and Pesaran (2004) tests for cross-sectional dependence confirms the presence of heteroscedasticity, autocorrelation and cross-sectional dependence. Because our analyzed period is shorter than the cross sectional unit, to deal with issues of contemporaneous correlation, the panel corrected standard error model (PCSE) is applied, controlling for heteroskedasticity and the $\mathrm{AR}(1)$ type autocorrelation and contemporaneous correlation across panels (Beck and Katz 1995, 1996). Second, due to time invariant variables we also employ FEVD models. Finally, we apply dynamic panel models to address the endogeneity issues. Our results are reasonable similar independently from the econometric approaches, thus we report only estimations based on dynamic panel models which able to solve more issues ${ }^{1}$.

Table 5 reports results on the drivers of VIIT. The GMM system estimator is consistent if there is no second-order serial correlation in the residuals. Dynamic models present consistent estimates, with no second order serial correlation (AB2 statistic) for the GMM system estimators. The specified Sargan test shows that there are no problems with the validity of the instruments used. We used the criterion of Windmeijer (2005) to small sample correction. However, unusual high p values suggest that many instruments (70) may present the weakness of Sargan test (Baltagi, 2008). Results are quite similar for the three dependent variables. Surprisingly, lagged VIIT variables are negative and significant for GHM and N models, contrary to Faustino and Leitão (2007) and Leitão (2011). This suggests year to year fluctuations in the VIIT values highlighting an instable pattern of VIIT between Hungary and its partners. The lnDGDPC variable is significant with expected sign for $\mathrm{N}$ specifications. Our findings are in line with Rasekhi and Shojaee (2012), who find also positive relationship

\footnotetext{
${ }^{1}$ Results based on PCSE and FEVD models are available from authors upon requests.
} 
between VIIT and GDP per capita differences. Using GHM index, our result is similar to other studies on manufacturing sectors, our results do not support comparative advantage explanation of VIIT (Milgram-Baleix and Moro-Egido 2010).

Contrary to Fertő (2005) and Rasekhi and Shojaee (2012), the sign of the land factor (lnDLAND) is unexpectedly negative and significant for all specifications. The other two factor endowment variables $\ln \mathrm{DLAB}$ and $\operatorname{lnDMACH}$ have positive signs and they are significant jointly except FF model. These studies reveal that the nature of factor endowments is important for VIIT. In line with previous studies for total trade (e.g. Blanes and Martin 2000; Mora 2002; Jensen and Lüthje 2009; Milgram-Baleix and Moro-Egido 2010), we find that differences in human and/or technological capital have rather positive impacts on VIIT.

\section{PLEASE INSERT TABLE 5 HERE}

The coefficients of lnAVGDP are positive and significant for all specifications, confirming hypothesis 2. In other words, the VIIT will grow with market size. The lnDGINI variable is significant in four out of the six specifications. The income distribution overlap variables are significant with expected signs for FF and N specifications supporting hypothesis 4. Distance has negative and significant impact for all specifications. This suggests that trade costs are negatively influencing the VIIT. The NMS variable positively influences the share of VIIT for FF and N models. This implies that agri-food trade with NMS has positive impact on VIIT. However, EU accession has a positive effect on VIIT only for baseline GHM and N models, while it is negative for the augmented FF and N specifications. In short, the impacts of the EU accession are rather contradictory.

\section{Summary and conclusions}


This paper investigated the drivers of vertical intra-industry trade in the case of the Hungarian agri-food trade with the EU. It identified three possible ways to measure intra-industry trade flows (GHM, FF and N methods) and have defined six hypotheses to test for the drivers of VIIT with three panel data models (static, dynamic, FEVD).

On the basis of general trade patterns, showing that intra-industry trade is mainly vertical in nature, we have concentrated on the vertical part of IIT in the model runs. Results suggest that relative factor endowments especially those related to agriculture, can definitely be treated as drivers of Hungarian agri-food VIIT with the EU. It was also shown that factor endowments are negatively related to VIIT, suggesting that similar factor endowments can lead to the trade of quality-differentiated agri-food produce. Results also show that economic size is positively and significantly related to VIIT, indicating that countries with different sizes are more likely to have a higher share of VIIT than those of similar sizes. Distance and IIT were found to be negatively related as is the common case in the standard gravity model, indicating that geographical proximity fosters agri-food trade (including VIIT). Results also suggest that VIIT is greater if an NMS is exporting agri-food produce to an NMS, while EU accession ambiguously influence the share of VIIT.

In general, it seems that our results are independent from model estimations as interestingly, they do not differ considerably as we a priori expected. Moreover, our results seem surprisingly robust across various measurement of ITT.

\section{Acknowledgement}

The authors gratefully acknowledge two anonymous referees for their helpful comments and suggestions on earlier drafts of this manuscript. This paper was supported by the János Bolyai Research Scholarship of the Hungarian Academy of Sciences. 


\section{References}

Ambroziak, L. 2012. FDI and intra-industry trade: theory and empirical evidence from the Visegrad Countries. International Journal of Economics and Business Research, 4(1-2), 180198.

Arellano, M., \& Bover, O. 1995. Another look at the instrumental variable estimation of errorcomponents models. Journal of Econometrics, 68(1), 29-51.

Bakucs, L. Z., Fertö, I., Hockmann, H., \& Perekhozhuk, O. (2010). Estimating Oligopsony Power in the Hungarian Market for Slaughter Hogs. Eastern European Economics, 48(1), 6478.

Baltagi, B., Bresson, G., \& Pirotte, A. 2003. Fixed effects, random effects or Hausman Taylor? A pretest estimator. Economic Letters, 79, 361-369.

Baltagi, B.H. 2008. Econometric Analysis of Panel Data. John Wiley and Sons.

Beck, N., \& Katz, J. N. 1995. What to Do (and Not to Do) with Time-Series Cross-Section Data. American Political Sciences Review, 89(3), 634-647.

Beck, N., \& Katz, J. N. 1996. Nuisance vs. Substance: Specifying and Estimating Time-Series Cross-Section Models. Political Analysis, 6(1), 1-36.

Blanes, J. V. \& Martín, C. 2000. The nature and causes of intra-industry trade: Back to the comparative advantage explanation? The case of Spain. Review of World Economics, 136(3), 423-441.

Blundell, R., \& Bond, S. 1998. Initial conditions and moment restrictions in dynamic panel data models. Journal of Econometrics, 87(1), 115-143.

Bojnec, S., \& Fertő, I. 2012. Does EU enlargement increase agro-food export duration? The World Economy, 35(5), 609-631.

Brülhart, M. 2009. An Account of Global Intra-industry Trade, 1962-2006. The World Economy, 32(3), 401-459. 
Caetano, J., \& Galego, A. 2007. In Search for Determinants of intra-industry trade within an Enlarged Europe. South-Eastern Europe Journal of Economics, 5(2), 163-183.

Černoša, Š. 2009. Intra-Industry Trade and Industry-Specific Determinants in Slovenia: Manual Labour as Comparative Advantage. Eastern European Economics, 47(3), 84-99.

Copeland, B. R., \& Kotwal, A. (1996). Product quality and the theory of comparative advantage. European Economic Review, 40(9), 1745-1760.

Davies R.B., Ionascu D and Kristjánsdóttir, H. 2008. Estimating the impact of time-invariant variables on FDI with fixed effects. Review of World Economics, 144(3): 381-407

Fainštein, G., \& Netšunajev, A. 2011. Intra-Industry Trade Development in the Baltic States. Emerging Markets Finance and Trade, 47(3), 95-110.

Falvey, R. 1981. Commercial policy and intra-industry trade. Journal of International Economics, 11(4), 495-511.

Falvey, R. \& Kierzkowski, H. 1987. Product Quality, Intra-Industry Trade and (Im)Perfect Competition. In Kierzkowski, H. (Ed.), Protection and Competition in International Trade. Essays in Honor of W.M. Corden. Oxford: Blackwell

Faustino, H. C., \& Leitão, N. C. 2007. Intra-industry trade: a static and dynamic panel data analysis. International Advances in Economic Research, 13(3), 313-333.

Fertő, I. 2005. Vertically Differentiated Trade and Differences in Factor Endowment: The Case of Agri-Food Products between Hungary and the EU. Journal of Agricultural Economics, 56(1), 117-134.

Fertő, I. 2007. Intra-industry trade in horizontally and vertically differentiated agri-food products between Hungary and the EU. Acta Oeconomica, 57(2), 191-208.

Fertő, I. \& Soós, K. A. 2009. Treating trade statistics inaccuracies: the case of intra-industry trade. Applied Economics Letters. 16(18), 1861-1866. 
Flam, H. \& Helpman, E. 1987. Vertical Product Differentiation and North-South Trade. American Economic Review, 77(5), 810-822.

Fontagné, L. and Freudenberg, M. 1997. Intra-industry trade: Methodological issues reconsidered. CEPII Working Papers, 97-01.

Fontagné, L., Freudenberg, M., \& Gaulier, G. 2006. A systematic decomposition of world trade into horizontal and VIIT. Review of World Economics, 142(3), 459-475.

Gabrisch, H. 2009. Vertical intra-industry trade, technology and income distribution: a panel data analysis of EU trade with Central-East European Countries. Acta Oeconomica, 59(1), 122.

Gabszewicz, J., A. Shaked and J. Sutton 1981. International Trade in Differentiated Products. International Economic Review, 22(3), 527-34.

Greenaway, D., Hine, R. C., \& Milner, C. R. 1995. Vertical and Horizontal Intra-Industry Trade: A Cross-Industry Analysis for the United Kingdom. Economic Journal, 105(11), 15051518

Grubel, H., \& Lloyd, P. 1975. Intra-industry Trade The Theory and Measurement of International Trade in Differentiation Products. The Mcmillan Press: London, UK.

Hausman, J.A., \& Taylor, W.E. 1981. Panel data and unobservable individual effects. Econometrica, 49(6), 1377-1398.

Hirsch, S., \& Gschwandtner, A. 2013. Profit persistence in the food industry: evidence from five European countries. European Review of Agricultural Economics, first published online May 16, 2013, doi:10.1093/erae/jbt007

Hockmann, H., \& Vöneki, É. (2009). Collusion in the Hungarian market for raw milk. Outlook on agriculture, 38(1), 39-45.

Hummels, D., \& Levinsohn, J. 1995. Monopolistic Competition and International Trade: Reconsidering the Evidence. Quarterly Journal of Economics, 110(3), 799-836. 
Im, K., Pesaran, H., \& Shin, Y. 2003. Testing for unit roots in heterogeneous panels. Journal of Econometrics, 115(1), 53-74.

Jensen, L., \& Lüthje, T. 2009. Driving forces of vertical intra-industry trade in Europe 19962005. Review of World Economics, 145(3), 469-488.

Leitão, N. C., \& Faustino, H. 2008. Intra-industry trade in the food processing sector: the Portuguese case. Journal of Global Business and Technology, 4(1), 49-58.

Leitão, N. C. 2011. Intra-industry trade in the agriculture sector: The experience of United States. African Journal of Agricultural Research, 6(1), 186-190.

Levin, A., Lin, C. \& Chu, C. 2002. Unit root tests in panel data: asymptotic and finite-sample properties. Journal of Econometrics, 108(1), 1-24.

Linder, S. B. 1961. An Essay on Trade and Transformation. John Wiley, New York, USA

McCorriston, S., \& Sheldon, I.M. 1991. Intra-Industry Trade and Specialization in Processed Agricultural Products: The Case of the US and the EC. Review of Agricultural Economics, 13(2), 173-184.

Milgram-Baleix, J., \& Moro-Egido, A. I. 2010. The Asymmetric Effect of Endowments on Vertical Intra-industrial Trade. The World Economy, 33(5), 746-777.

Mitze, T. 2012. Estimating Gravity Models of Trade with Correlated Time-Fixed Regressors: To IV or not IV?. In Empirical Modelling in Regional Science (pp. 165-190). Springer Berlin Heidelberg.

Mora, C. D. 2002. The role of comparative advantage in trade within industries: A panel data approach for the European Union. Review of World Economics, 138(2), 291-316.

Ng, S., \& Perron, P. 2001. Lag length selection and the construction of unit root tests with good size and power. Econometrica 69, 1519-1554.

Nilsson, L. 1997. The Measurement of Intra-Industry Trade between Unequal Partners. Weltwirtschaftliches Archiv, 133(3), 554-565. 
Perekhozhuk, O., Hockmann, H., Fertő, I., \& Bakucs, L. Z. (2013). Identification of Market Power in the Hungarian Dairy Industry: A Plant-Level Analysis. Journal of Agricultural \& Food Industrial Organization, 11(1), 1-13.

Pesaran, M.H. 2004. General diagnostic tests for cross section dependence in panels. Cambridge: University of Cambridge, Faculty of Economics, Cambridge Working Papers in Economics No. 0435.

Plümper T., \& Troeger V.E. 2007. Efficient estimation of time-invariant and rarely changing variables in finite sample panel analyses with unit fixed effects. Political Analysis 15(2):124139

Qasmi, B.A, \& Fausti, S.W. 2001. NAFTA intra-industry trade in agricultural food products. Agribusiness: An International Journal, 17(2), 255-271.

Rasekhi, S., \& Shojaee, S. S. 2012. Determinant factors of the vertical intra-industry trade in agricultural sector: a study of Iran and its main trading partners. Agricultural Economics (Zemědelská Ekonomika), 58(4), 180-190.

Shaked, A. and Sutton, J. 1984. Natural Oligopolies and International Trade. in H. Kierzkowski (ed.), Monopolistic Competition and International Trade (New York: Oxford University Press).

Sexton, R.J., Lavoie, N. (2001), "Food Processing and Distribution: An Industrial Organization Approach", in: Gardner, B. and Rausser, G., Handbook of Agricultural Economics, Elsevier Science B.V., 863-923.

Sheldon, I.M., Sperling, R. (2003), "Estimating the extent of imperfect competition in the food industry: what have we learned?”, Journal of Agricultural Economics, 51(1), 89-109.

Stokey, N. L. (1991). The volume and composition of trade between rich and poor countries. Review of Economic Studies, 58(1), 63-80.

Varma, P. 2012. An analysis of India's bilateral intra-industry trade in agricultural products. International Journal of Economics and Business Research, 4(1), 83-95.

Wang, J. 2009. The analysis of intra-industry trade on agricultural products of China. Frontiers of Economics in China, 4(1), 62-75. 
Windmeijer, F. 2005. A finite sample correction for the variance of linear efficient two-step GMM estimators. Journal of Econometrics, 126(1), 25-51.

Wooldridge, J.M. 2002. Econometric Analysis of Cross Section and Panel Data. Cambridge, Massachusetts: The MIT Press. 
TABLES AND FIGURES

Table 1: Summary of Econometric Evidence for agri-food VIIT in the NMS

\begin{tabular}{|c|c|c|c|c|c|}
\hline Year & Author & $\begin{array}{l}\text { Country } \\
\text { Coverage }\end{array}$ & Period & Methodology & Signs on VIIT \\
\hline 2005 & Fertő & $\begin{array}{l}\text { Hungary and } \\
\text { EU15 }\end{array}$ & $\begin{array}{c}1992- \\
1998\end{array}$ & $\begin{array}{l}\text { Panel } \\
\text { regression }\end{array}$ & $\begin{array}{c}\text { DGDPC: + DGDP: + } \\
\text { Human Capital: + } \\
\text { Land: + Distance: - } \\
\text { Capital: - }\end{array}$ \\
\hline 2007 & Fertő & $\begin{array}{l}\text { Hungary and } \\
\text { EU15 }\end{array}$ & $\begin{array}{c}1992- \\
1998\end{array}$ & $\begin{array}{c}\text { Generalised } \\
\text { estimating } \\
\text { equation } \\
\end{array}$ & $\begin{array}{c}\text { DGDPC: + AVGDP: - } \\
\text { Distance: + } \\
\text { Gini: - } \\
\end{array}$ \\
\hline 2008 & $\begin{array}{l}\text { Leitao- } \\
\text { Faustino }\end{array}$ & $\begin{array}{l}\text { Portugal and } \\
\text { EU15 }\end{array}$ & $\begin{array}{l}1995- \\
2003\end{array}$ & OLS & $\begin{array}{c}\text { DGDP: + EP: - } \\
\text { EC: + MinGDP: - } \\
\text { MaxGDP: - DIST: - }\end{array}$ \\
\hline 2011 & Leitao & $\begin{array}{c}\text { USA and } \\
\text { NAFTA, } \\
\text { EU, ASEAN } \\
\end{array}$ & $\begin{array}{l}1995- \\
2008\end{array}$ & $\begin{array}{c}\text { Fixed effects } \\
\text { and GMM- } \\
\text { SYS } \\
\end{array}$ & $\begin{array}{c}\text { DGDP: - AVGDP: + } \\
\text { FDI: + TIMB: - }\end{array}$ \\
\hline 2012 & $\begin{array}{l}\text { Rasekhi- } \\
\text { Shojaee }\end{array}$ & $\begin{array}{c}\text { Iran and } 24 \\
\text { countries }\end{array}$ & $\begin{array}{l}2001- \\
2007\end{array}$ & Fixed effects & $\begin{array}{c}\text { DGDP: - AVGDP: - } \\
\text { Land: + }\end{array}$ \\
\hline 2007 & $\begin{array}{l}\text { Caetano- } \\
\text { Galego }\end{array}$ & $\begin{array}{l}\text { NMS and } \\
\text { EU15 }\end{array}$ & $\begin{array}{l}1993- \\
2001 \\
\end{array}$ & $\begin{array}{c}\text { FGLS, } \\
\text { random effects }\end{array}$ & $\begin{array}{c}\text { DGDPC: + DGDP: + } \\
\text { FDI: + Distance: - }\end{array}$ \\
\hline 2009 & $\begin{array}{l}\text { Jensen- } \\
\text { Lüthje }\end{array}$ & $\begin{array}{l}\text { Visegrad } \\
\text { Countries } \\
\text { and EU15 }\end{array}$ & $\begin{array}{l}1996- \\
2005\end{array}$ & OLS, GLS & $\begin{array}{c}\text { DGDPC: - DGDP: + } \\
\text { AVGDP: + } \\
\text { Human Capital: + } \\
\text { Land: - Capital: + } \\
\text { Distance: - }\end{array}$ \\
\hline 2009 & Gabrisch & $\begin{array}{l}\text { NMS and } \\
\text { EU15 }\end{array}$ & $\begin{array}{l}1993- \\
2004\end{array}$ & $\begin{array}{l}\text { Pooled } \\
\text { regression, } \\
\text { fixed effect, } \\
\text { random effect }\end{array}$ & $\begin{array}{l}\text { DGDPC: - } \\
\text { Capital: + } \\
\text { Distance: - }\end{array}$ \\
\hline 2011 & $\begin{array}{l}\text { Fainštein- } \\
\text { Netšunajev }\end{array}$ & $\begin{array}{c}\text { Baltic } \\
\text { Countries } \\
\text { and World }\end{array}$ & $\begin{array}{l}1999- \\
2007\end{array}$ & $\begin{array}{l}\text { Random } \\
\text { effects }\end{array}$ & $\begin{array}{c}\text { DGDPC: - DGDP: + } \\
\text { Human Capital: - } \\
\text { Capital: + Gini: + } \\
\text { Distance: - }\end{array}$ \\
\hline 2012 & Ambroziak & $\begin{array}{l}\text { Visegrad } \\
\text { Countries } \\
\text { and World }\end{array}$ & $\begin{array}{l}1995- \\
2008\end{array}$ & $\begin{array}{l}\text { Random } \\
\text { effects, Tobit }\end{array}$ & $\begin{array}{c}\text { DGDPC: + DGDP: + } \\
\text { FDI: + } \\
\text { Common border: + } \\
\text { Liberalised trade: + } \\
\text { Distance: - } \\
\end{array}$ \\
\hline
\end{tabular}

Abbreviations: DGDPC: difference in per capita GDP, DGDP: difference in GDP, AVGDP: average GDP, EP: physical endowments, EC: energy consumption, TIMB: trade imbalance Source: Own composition 
Table 2: Description of independent variables

\begin{tabular}{|c|c|c|c|}
\hline Variable & Variable description & Data source & Sign \\
\hline $\operatorname{lnDGDPC}$ & $\begin{array}{l}\text { The logarithm of per capita GDP absolute difference } \\
\text { between trading partners measured in PPP in current } \\
\text { international USD }\end{array}$ & WDI & + \\
\hline lnDLAND & $\begin{array}{l}\text { The logarithm of agricultural area absolute difference } \\
\text { between trading partners measured in million hectares }\end{array}$ & FAO & + \\
\hline $\operatorname{lnDLAB}$ & $\begin{array}{l}\text { The logarithm of agricultural labor absolute difference } \\
\text { between trading partners measured in } 1000 \text { annual } \\
\text { working units }\end{array}$ & Eurostat & + \\
\hline lnDMACH & $\begin{array}{l}\text { The logarithm of agricultural machinery absolute } \\
\text { difference between trading partners measured euro }\end{array}$ & FADN & + \\
\hline $\ln A V G D P$ & $\begin{array}{l}\text { The logarithm of average GDP of trading partners } \\
\text { measured in PPP in current international USD }\end{array}$ & WDI & + \\
\hline lnDGINI & $\begin{array}{l}\text { The logarithm of GINI absolute difference between } \\
\text { trading partners measured by the GINI index }\end{array}$ & WDI & + \\
\hline $\operatorname{lnDIST}$ & $\begin{array}{l}\text { The logarithm of absolute difference between trading } \\
\text { partners capital city measured in kilometers }\end{array}$ & CEPII & - \\
\hline NMS & dummy variable: 1 if NMS, otherwise zero & & $?$ \\
\hline EU & $\begin{array}{l}\text { dummy variable: } 1 \text { when Hungary is member of the EU, } \\
\text { otherwise zero }\end{array}$ & & + \\
\hline
\end{tabular}

Source: Own composition 
Figure 1: Development of IIT between Hungary and EU-26 using different measures

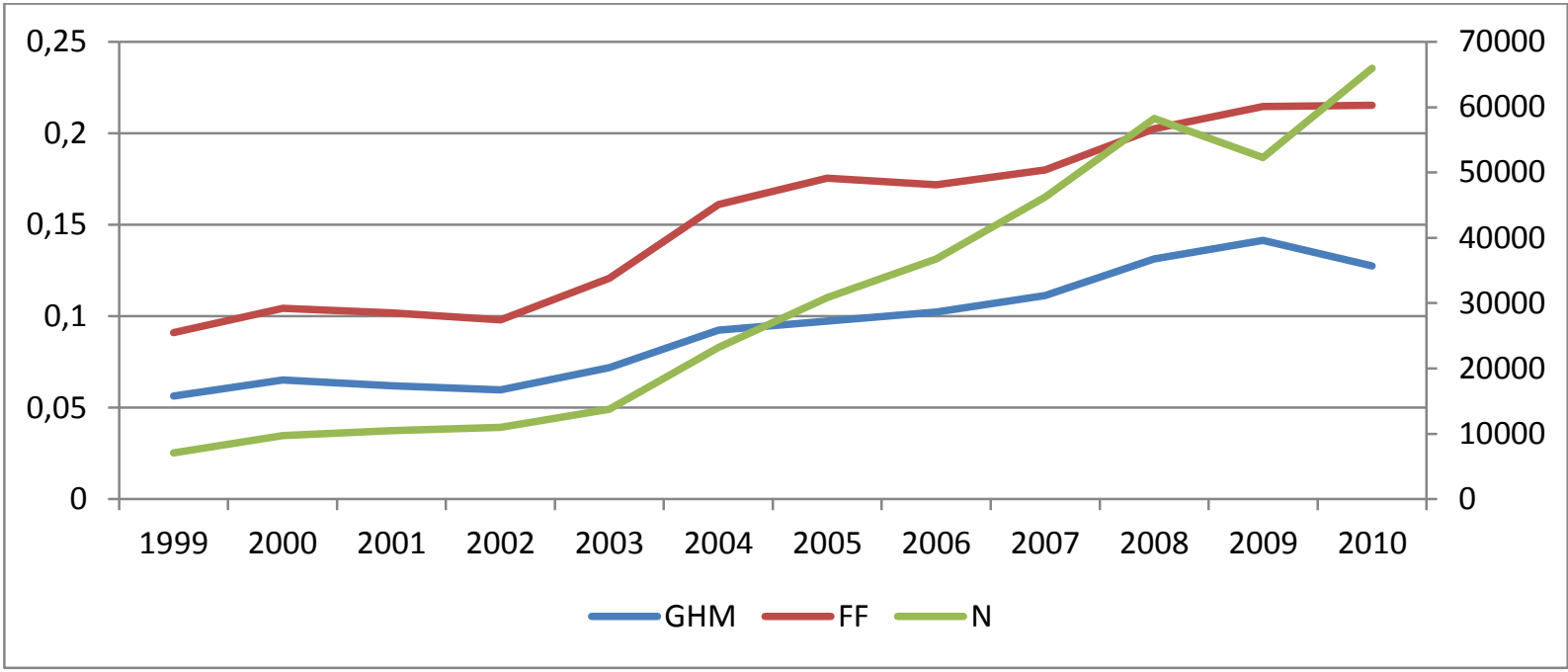

Source: Own calculations based on the Eurostat database

Figure 2: Types of IIT by market segments

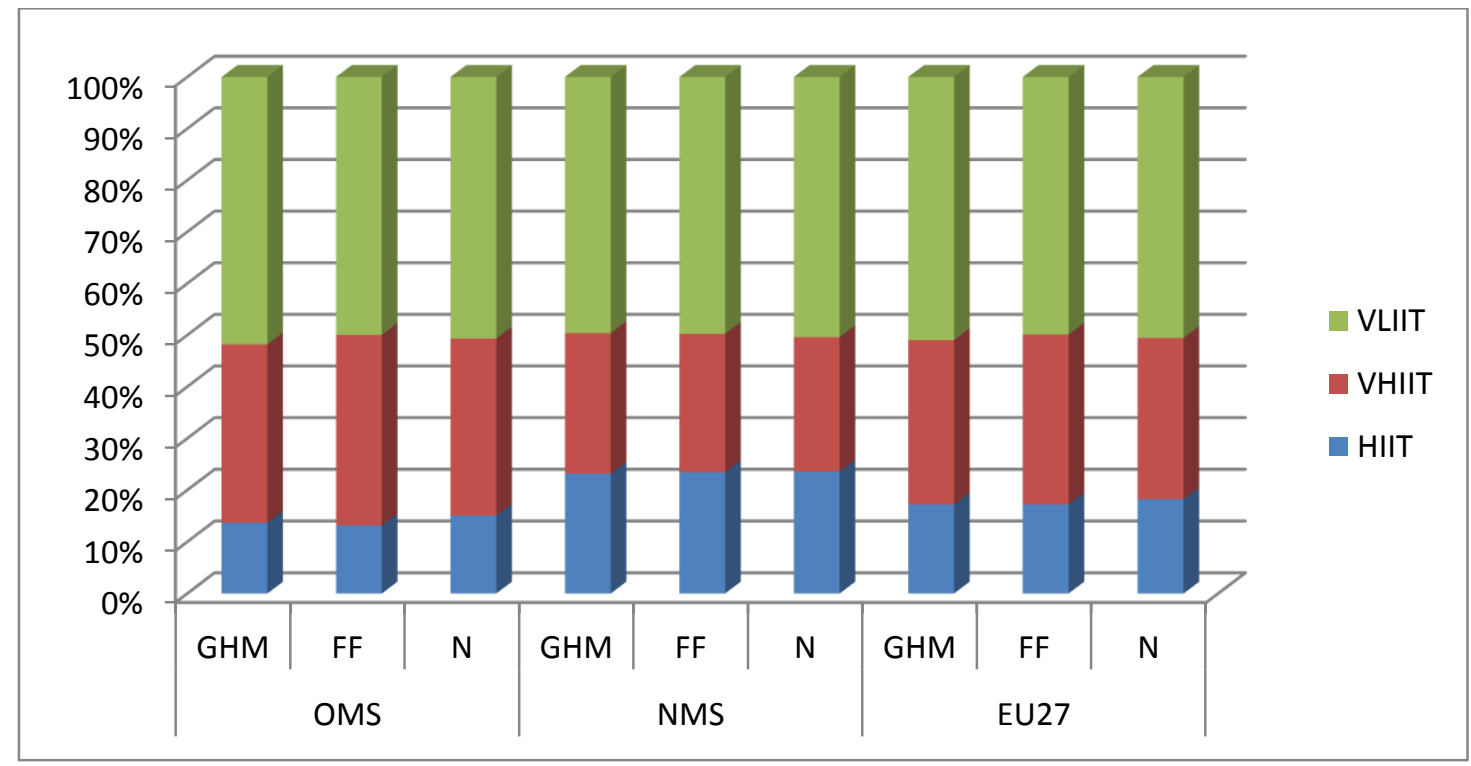

Source: Own calculations based on the Eurostat database 
Table 3: Correlation matrix for the explanatory variables

\begin{tabular}{|c|c|c|c|c|c|c|}
\hline & lnDGDPC & $\ln$ AVGDP & lnDLAND & lnDLAB & $\operatorname{lnDMACH}$ & $\operatorname{lnGINI}$ \\
\hline $\ln$ DGDPC & 1.0000 & & & & & \\
\hline $\ln$ AVGDP & 0.3203 & 1.0000 & & & & \\
\hline $\operatorname{lnDLAND}$ & 0.0702 & 0.4393 & 1.0000 & & & \\
\hline $\operatorname{lnDLAB}$ & -0.1139 & -0.2172 & 0.2748 & 1.0000 & & \\
\hline $\ln$ DMACH & 0.3643 & 0.3311 & 0.3006 & -0.2043 & 1.0000 & \\
\hline $\ln$ GINI & -0.0891 & -0.1295 & 0.1549 & 0.1523 & -0.0183 & 1.0000 \\
\hline
\end{tabular}

Source: Own estimations

Table 4: Panel unit root tests

\begin{tabular}{|c|c|c|c|c|c|c|c|c|}
\hline & GHM & $\mathrm{FF}$ & $\mathrm{N}$ & $\begin{array}{l}\operatorname{lnDG} \\
\mathrm{DPC}\end{array}$ & $\begin{array}{l}\ln A V \\
\text { GDP }\end{array}$ & $\begin{array}{l}\operatorname{lnDL} \\
\text { AND }\end{array}$ & $\begin{array}{l}\operatorname{lnDL} \\
\mathrm{AB}\end{array}$ & $\begin{array}{l}\mathrm{lnDM} \\
\mathrm{ACH}\end{array}$ \\
\hline Levin, Lin \& Chu t* & 0.000 & 0.013 & 0.735 & 0.012 & 0.000 & 1.000 & 0.000 & 1.000 \\
\hline $\begin{array}{l}\text { Im, Pesaran and Shin } \\
\text { W-stat }\end{array}$ & 0.000 & 0.295 & 0.842 & 0.809 & 0.000 & 1.000 & 0.664 & 0.993 \\
\hline $\begin{array}{l}\text { ADF - Fisher Chi- } \\
\text { square }\end{array}$ & 0.000 & 0.020 & 0.042 & 0.887 & 0.001 & 1.000 & 0.933 & 0.996 \\
\hline PP - Fisher Chi-square & 0.000 & 0.000 & 0.000 & 0.987 & 0.000 & 1.000 & 0.632 & 1.000 \\
\hline with trend & & & & & & & & \\
\hline Levin, Lin \& Chu t* & 0.000 & 0.000 & 0.000 & 0.000 & 1.000 & 1.000 & 0.005 & 1.000 \\
\hline $\begin{array}{l}\text { Im, Pesaran and Shin } \\
\text { W-stat }\end{array}$ & 0.000 & 0.000 & 0.000 & 0.221 & 1.000 & 1.000 & 0.193 & 1.000 \\
\hline $\begin{array}{l}\text { ADF - Fisher Chi- } \\
\text { square }\end{array}$ & 0.000 & 0.000 & 0.000 & 0.141 & 1.000 & 1.000 & 0.354 & 1.000 \\
\hline PP - Fisher Chi-square & 0.000 & 0.000 & 0.000 & 0.968 & 1.000 & 0.991 & 0.999 & 1.000 \\
\hline
\end{tabular}

Source: Own estimations

Table 5: Determinants of VIIT in the agri-food sectors (GMM-Systems models)

\begin{tabular}{|c|c|c|c|}
\hline & GHM-index & FF-index & N-index \\
\hline
\end{tabular}




\begin{tabular}{|c|c|c|c|c|c|c|}
\hline & Baseline & Augmented & Baseline & $\begin{array}{l}\text { Augmente } \\
\text { d }\end{array}$ & Baseline & Augmented \\
\hline L1.VIIT & $\begin{array}{l}- \\
0.3596^{* * * *}\end{array}$ & $-0.3827 * * *$ & 0.0279 & -0.0250 & $-0.5884 * * *$ & $-0.5466 * * *$ \\
\hline $\operatorname{lnDGDPC}$ & $\begin{array}{l}- \\
0.0040^{* * * *}\end{array}$ & & 0.0002 & & $\begin{array}{l}899.1425^{*} \\
* *\end{array}$ & \\
\hline $\begin{array}{l}\text { InDLAN } \\
\text { D }\end{array}$ & & $-0.0102 * * *$ & & $-0.0160 * * *$ & & $\begin{array}{l}- \\
8.4 \mathrm{e}+03 * * *\end{array}$ \\
\hline $\operatorname{lnDLAB}$ & & $0.0042 * * *$ & & 0.0015 & & $5.6 \mathrm{e}+03 * * *$ \\
\hline $\begin{array}{l}\operatorname{lnDMAC} \\
\mathrm{H}\end{array}$ & & $0.0008 * * *$ & & $0.0035 * * *$ & & $\begin{array}{l}635.8203^{* *} \\
*\end{array}$ \\
\hline lnAVGDP & $0.0043 * * *$ & 0.0002 & $\begin{array}{l}0.0872 * * \\
*\end{array}$ & $0.0897 * * *$ & $\begin{array}{l}4.3 e+04 * * \\
*\end{array}$ & $3.9 \mathrm{e}+04 * * *$ \\
\hline InDGINI & $\begin{array}{l}- \\
0.0003^{* * *}\end{array}$ & -0.0001 & $\begin{array}{l}0.0015 * * \\
*\end{array}$ & $0.0015 * * *$ & 10.9423 & $\begin{array}{l}125.3178^{* *} \\
*\end{array}$ \\
\hline lnDIST & $\begin{array}{l}- \\
0.0386^{* * * *}\end{array}$ & $-0.0451 * * *$ & $\begin{array}{l}- \\
0.1183 * * \\
*\end{array}$ & $-0.0967 * * *$ & $\begin{array}{l}- \\
3.2 \mathrm{e}+04 * * \\
*\end{array}$ & $\begin{array}{l}- \\
2.8 \mathrm{e}+04^{* * *}\end{array}$ \\
\hline NMS & 0.0095 & 0.0134 & 0.0448 & $0.1072 * *$ & $9.4 \mathrm{e}+03^{*}$ & $-8.9 e+02$ \\
\hline $\mathrm{EU}$ & $0.0073^{* * *}$ & 0.0017 & -0.0039 & $-0.0144 * * *$ & $\begin{array}{l}1.3 e+03 * * \\
*\end{array}$ & $\begin{array}{l}- \\
1.5 \mathrm{e}+03^{* * *}\end{array}$ \\
\hline constant & $0.1931 * *$ & $0.2892 * * *$ & $\begin{array}{l}- \\
1.4729 * * \\
*\end{array}$ & $-1.7101 * * *$ & $\begin{array}{l}- \\
9.2 \mathrm{e}+05^{* *} \\
*\end{array}$ & $8.5 \mathrm{e}+05^{* * * *}$ \\
\hline
\end{tabular}




\begin{tabular}{|l|l|l|l|l|l|l|}
\hline $\begin{array}{l}\text { N (no. of } \\
\text { observatio } \\
\text { ns) }\end{array}$ & 286 & 286 & 286 & 286 & 286 & 286 \\
\hline $\begin{array}{l}\text { Number } \\
\text { of } \\
\text { instrumen } \\
\text { ts }\end{array}$ & 70 & 72 & 70 & 72 & 70 & 72 \\
\hline $\begin{array}{l}\text { Wald test } \\
\text { (p-value) }\end{array}$ & 0.0000 & 0.0000 & 0.0000 & 0.0000 & 0.0000 & 0.0000 \\
\hline $\begin{array}{l}\text { AB1 } \\
\text { (p-value) }\end{array}$ & 0.0582 & 0.0625 & 0.0711 & 0.0956 & 0.1879 & 0.1584 \\
\hline $\begin{array}{l}\text { AB2 } \\
\text { (p-value) }\end{array}$ & 0.2073 & 0.2231 & 0.3253 & 0.3436 & 0.2119 & 0.3101 \\
\hline $\begin{array}{l}\text { Sargan } \\
\text { test } \\
\text { (p-value) }\end{array}$ & 1.0000 & 1.0000 & 1.0000 & 1.0000 & 1.0000 & 1.0000 \\
\hline Soure: Own & & & & & \\
\hline
\end{tabular}

Source: Own estimations

Note: N: number of observations. $* * * / * * / *$ : statistically significant, respectively at the $1 \%, 5 \%$, and $10 \%$ levels. AB1 AB2 are tests for first-order and second-order autocorrelation 